
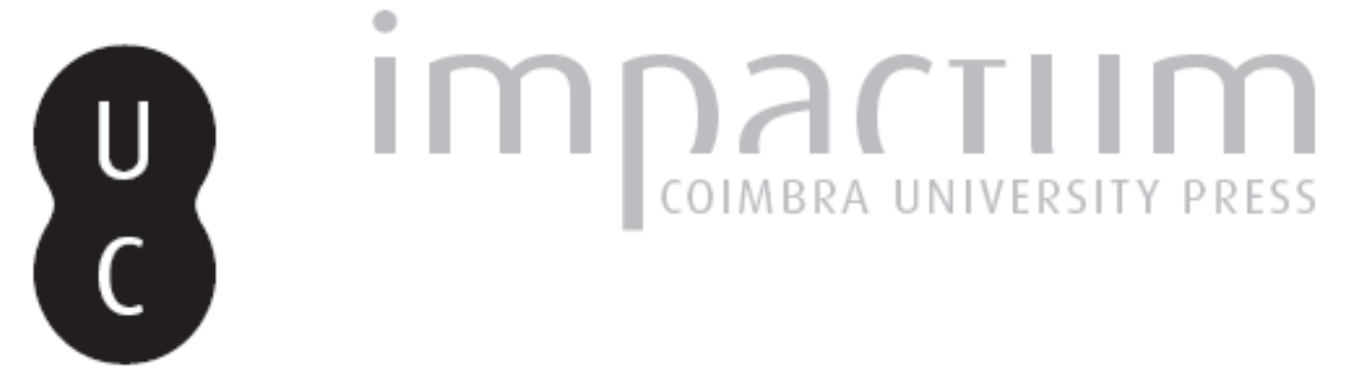

\title{
A religião de Lusitanos e Calaicos
}

\section{Autor(es): $\quad$ Alarcão, Jorge de}

Publicado por: Faculdade de Letras da Universidade de Coimbra

URL persistente:

URI:http://hdl.handle.net/10316.2/37821

DOI:

DOI:http://dx.doi.org/10.14195/1647-8657_48_3

Accessed : $\quad$ 26-Apr-2023 06:01:46

A navegação consulta e descarregamento dos títulos inseridos nas Bibliotecas Digitais UC Digitalis, UC Pombalina e UC Impactum, pressupõem a aceitação plena e sem reservas dos Termos e Condições de Uso destas Bibliotecas Digitais, disponíveis em https://digitalis.uc.pt/pt-pt/termos.

Conforme exposto nos referidos Termos e Condições de Uso, o descarregamento de títulos de acesso restrito requer uma licença válida de autorização devendo o utilizador aceder ao(s) documento(s) a partir de um endereço de IP da instituição detentora da supramencionada licença.

Ao utilizador é apenas permitido o descarregamento para uso pessoal, pelo que o emprego do(s) título(s) descarregado(s) para outro fim, designadamente comercial, carece de autorização do respetivo autor ou editor da obra.

Na medida em que todas as obras da UC Digitalis se encontram protegidas pelo Código do Direito de Autor e Direitos Conexos e demais legislação aplicável, toda a cópia, parcial ou total, deste documento, nos casos em que é legalmente admitida, deverá conter ou fazer-se acompanhar por este aviso.

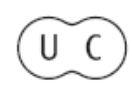


CONIMBRIGA

W.

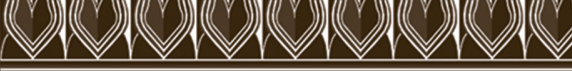

INSTITUTO DE ARQUEOLOGIA

VOLUME XLVIII • 2009

FACULDADE DE LETRAS 
JoRge De AlARCÃo

Professor Catedrático aposentado da Faculdade de Letras de Coimbra

Membro do Centro de Estudos Arqueológicos das Universidades de Coimbra e Porto

\section{A RELIGIÃO DE LUSITANOS E CALAICOS \\ "Conimbriga" XLVIII (2009) p. 81-121}

Resumo: Lusitani e Callaeci eram duas etnias proto-históricas do Noroeste peninsular, aparentadas mas com consciência também das suas diferenças. Tinham, como divindades comuns, Bandue/Bandi, Reve e Nabia. Como divindades específicas, os Lusitani adoravam Arentius e Arentia, Quangeius e Trebarune. Os Callaeci, por seu turno, tinham, como divindades próprias, Cossue/Coso e Crougiai. $\mathrm{O}$ autor tenta definir as funções destas divindades. Os numerosos outros teónimos que se conhecem através de inscrições votivas corresponderão a simples genii loci.

RÉsumé: Lusitani et Callaeci étaient deux ethnies proto-historiques du nordouest de la Péninsule Ibérique avec beaucoup de traits communs. Les dieux Bandue/Bandi, Reve et Nabia étaient communs aux deux ethnies. Les Lusitani avaient comme dieux spécifiques, Arentius et Arentia, Quangeius et Trebarune, tandis que Cossue/Coso et Crougiai étaient propres aux Callaeci. L'auteur se propose de discuter les fonctions de ces divinités. Les nombreux autres théonymes connus par des inscriptions votives correspondraient à des simples genii loci. 
(Página deixada propositadamente em branco) 


\section{A RELIGIÃO DE LUSITANOS E CALAICOS}

\section{Introdução}

O presente artigo sugere, mais do que demonstra. Procurando reconstituir o panteão de Lusitani e de Callaeci e definir a função dos deuses, entretecemos conjecturas, sustentadas, é certo, por argumentos, mas não comprovadas por factos indisputáveis.

Se um pressuposto é um juízo que se forma sem se ter jamais pensado no juízo contraditório ou, pelo menos, num juízo alternativo, as ideias que aqui apresentamos não envolvem pressupostos. Poderemos dizer que envolvem postulados - os quais são juízos não evidentes mas por nós admitidos dado não vermos outros que permitam entender ou explicar melhor os factos. Tornaremos claros os postulados nos momentos oportunos do nosso discurso hermenêutico. Construímos um modelo, partindo do princípio de que o panteão de Lusitani e Callaeci não seria uma mera soma de deuses, mas uma totalidade organizada que, para os indígenas, explicava o mundo e a sociedade, ao mesmo tempo que pretendia regê-los. O modelo procura explicar variáveis integrando-as num sistema organizado e equacionando-as com determinados dados ou observações, tendo, porém, consciência de que pode haver explicações alternativas, mesmo se não entrevemos claramente que alternativas podem ser essas.

O presente artigo é também um desafio ou um convite. Em primeiro lugar, aos linguistas. Com efeito, na investigação sobre as funções dos deuses devemos guiar-nos (na ausência de outras fontes) pelas análises linguísticas que procuram determinar as raízes dos teónimos ou epítetos. Nem todos os linguistas estão, porém, de acordo nas suas análises, como se verifica, por exemplo, nos casos de Bandue/ Bandi ou de Cossue/Coso. Quando os linguistas divergem, optámos por 
aquela etimologia que conduz a uma interpretação a nosso ver mais credível da função da divindade. Mas a nossa proposta (ou a nossa opção) deve ser reconsiderada pelos linguistas.

Em segundo lugar, desafiamos os historiadores das religiões comparadas. Tendo assumido que, sendo indo-europeias as etnias de Lusitani e Callaeci, deve haver alguma correspondência com o panteão arcaico dos Gregos ou o dos Romanos, assim como com o panteão dos Celtas, não levámos tão longe quanto possível ou desejável a comparação com aquelas religiões. As nossas propostas devem ser, por isso, aprofundadas.

Em terceiro lugar, as nossas interpretações devem ser examinadas também por quem, dedicando-se à Proto-História do Ocidente peninsular, se interessa particularmente por questões antropológicas, isto é, pelos aspectos sociopolíticos ou socioeconómicos.

As inscrições votivas que neste artigo utilizámos encontram-se nas obras de José d' Encarnação (1975), José Manuel Garcia (1991) ou Blanca María Prósper (2002), que dão, delas, os textos completos, os lugares de achado e a bibliografia relevante. Julgámos inútil, por isso, repetir o que nessas obras, indispensáveis e acessíveis, facilmente se encontra. Apenas damos referências bibliográficas das inscrições que não se acham registadas naqueles estudos (ou, em alguns casos, de leituras ou interpretações que aquelas obras não recolheram).

Por opção metodológica, não tivemos em atenção nem as dimensões das aras, nem os dedicantes, nem os contextos de achado. Estes aspectos poderão ser, todavia, relevantes, mesmo quando a perspectiva é a de definir a função dos deuses e não a de equacionar os cultos com classes socioeconómicas ou socioculturais. Das dimensões das aras e dos contextos de achado poderá, nalguns casos, deduzir-se se foi privado ou público o ritual em torno de tais aras. Nalguns casos, é óbvio que o ritual foi público: quando, por exemplo, uma ara foi consagrada por uns vicani. Se o carácter público ou privado dos rituais é mais importante para identificar lugares de culto, talvez, indirectamente, possa contribuir para esclarecer a função dos deuses.

Quanto a lugares públicos de culto, e não obstante a existência de alguns estudos, carecemos de uma abordagem sistemática que nos permita fazer ideia dos lugares onde as divindades eram adoradas: seria 
comum a existência de modestos templos? Os cultos indígenas seriam maioritariamente praticados em lugares naturais como grutas, fragas, recintos não monumentalizados ainda que de algum modo demarcados?

Os teónimos conhecem-se através de inscrições votivas, que os apresentam no dativo. Reconstituímos os nominativos, excepto nos casos em que o tema morfológico é tão duvidoso que os autores preferem referir-se às divindades mantendo os nomes na(s) forma(s) do dativo.

Adoptámos as abreviaturas correntes de IE para indo-europeu e airl. para antigo irlandês. As transcrições fonéticas que fazemos de raízes indo-europeias poderão ser, algumas vezes, menos correctas ou menos completas; mas, consideradas as dificuldades de representação tipográfica, e atendendo ao facto de a correcção ser exigência de estudos linguísticos mas não ser indispensável num trabalho como o nosso, parecem-nos menos relevantes as incorrecções que nos poderão ser imputadas. Nas obras de linguistas de que nos servimos (e que mencionamos) encontrar-se-ão, aliás, as transcrições devidamente feitas de acordo com as normas actualmente adoptadas nos estudos de linguística indo-europeia.

\section{Revisão sumária dos estudos anteriores.}

Foi Leite de Vasconcelos quem primeiro coligiu, de forma sistemática, os teónimos indígenas do Ocidente peninsular (em Religiões da Lusitânia, vols. II, 1905 e III, 1913).

Nas décadas de 1960 e 1970, as divindades indígenas foram objecto de outros importantes estudos sistemáticos: José María Blázquez publicou Religiones primitivas de Hispania (1962) e José d' Encarnação apresentou Divindades indígenas sob o domínio romano em Portugal (1975). Esta segunda obra optou por uma ordenação dicionarista; isto é, reunindo todos os teónimos então conhecidos em Portugal, apresentou-os por ordem alfabética. A mesma ordenação viria a ser adoptada por José María Blázquez num novo volume que saiu, tal como o de José d' Encarnação, no ano de 1975: Diccionario de las religiones prerromanas de Hispania.

A lista das divindades aumentou consideravelmente desde então, graças ao achado de novas inscrições votivas. Muitas trouxeram novos teónimos ou novos epítetos; outras confirmaram teónimos já conhecidos, 
alargando ou adensando as cartas de distribuição das divindades. Novos achados de epígrafes ou releituras de inscrições de há muito conhecidas permitiram, ao mesmo tempo, corrigir antigas leituras. A maior parte dos teónimos surge em aras de granito gastas ou incompletas e, por isso, de leitura frequentemente difícil. Às vezes, as letras foram avivadas por quem não entendeu devidamente o que lia. Noutros casos, as inscrições perderam-se e não dispomos, hoje, senão das transcrições de quem as viu e copiou nem sempre correctamente. As releituras, quer de aras existentes, quer de cópias das que se perderam, têm permitido a correcção de teónimos. Assim, Duangeius foi corrigido para Quangeius, ou Dipaincia, para Oipaengia.

A obra de José Manuel Garcia, Religiões antigas de Portugal (1991), actualizou a de José d' Encarnação, sem ter, todavia, tornado esta dispensável; e a de Juan Carlos Olivares Pedreño, Los dioses de la Hispania Céltica (2002), reuniu os teónimos para o conjunto da Hispânia comummente dita céltica.

Esta última obra agrupou as divindades por áreas geográficas. Aliás, já Alain Tranoy, em La Galice romaine (1981), havia feito um agrupamento geográfico, distinguindo as divindades da antiga Calécia por conventus: Bracarum, Lucensis e Asturum.

Outros agrupamentos têm sido feitos. José María Blázquez (1962) distinguiu: deuses assimilados a Tutela; deuses solares, da vegetação, protectores do gado, aquáticos, da fecundidade, com carácter de benfazejos; deuses da guerra, funerários, etc. Por seu turno, Blanca María Prósper, em Lenguas y religiones prerromanas del Occidente de la Península Ibérica (2002), distinguiu: divindades fluviais (dando particular relevo a um suposto deus das confluências, Cossue/Coso); deuses de montes, penhascos e vales; divindades de campos, bosques e prados. De Bandue/Bandi fez um deus da paisagem. E reuniu muitos outros num grupo de "divindades de outra natureza". Elizabeth A. Richert (2005) distinguiu divindades das montanhas, das águas, protectoras e guerreiras, e, num grupo de "outras divindades", reuniu as que não classificou naquelas quatro categorias.

Desde os primeiros estudos sobre as divindades indígenas se procurou, através da análise linguística, determinar o sentido dos nomes e, assim, alcançar algum entendimento sobre a função das divindades. 
Neste domínio, a bibliografia é hoje vasta. Mas, entre todas, saliente-se, como obra sistemática, a já citada de Blanca María Prósper.

Se as análises linguísticas são essenciais para entendermos as funções das divindades indígenas, os linguistas, porém, divergem por vezes consideravelmente uns dos outros nas propostas etimológicas e alguns reconhecem quão importante é a confirmação (ou correcção ou denegação) das etimologias por dados não-linguísticos (VILLAR, 1996: 162).

Os dados não-linguísticos mais óbvios são os iconográficos, ainda que, pelo seu carácter simbólico, possam originar equívocas interpretações. Infelizmente, e ao contrário do que sucede na Gália, as representações de divindades indígenas do Ocidente peninsular são quase inexistentes.

Muito conhecida é a pátera em que surge uma representação de Band(i) Araugel(ensi), isto é, de Bandue /Bandi invocado pelos habitantes de um povoado Araocelum. A figura, aparentemente feminina (o que contraria o género masculino da divindade, atestado por numerosos epítetos), surge com uma coroa torreada. Foi este elemento iconográfico que levou A. Blanco Freijeiro (1959) a assimilar Bandue/ Bandi à Fortuna romana e José María Blázquez (1962: 51-61) a incluir o mesmo deus entre as divindades tutelares. Virgínia Muñoz (2005) também identificou Bandue/Bandi com Tutela. Deve ter-se em atenção, porém, que Bandue/Bandi está aqui representado como divindade tutelar de uma povoação. Como tal, leva a coroa torreada. Mas o símbolo iconográfico não aludirá à função primária ou original da divindade; representá-la-á numa função secundária. Se dispuséssemos de outras representações do mesmo deus, não o teríamos com outras iconografias? Os símbolos tanto revelam como enganam ou disfarçam.

O deus Tongus Nabiacus acha-se representado na Fonte do Ídolo, em Braga. A figura do deus, de corpo inteiro, barbudo, com cornucópia, recorda outras representações de divindades aquáticas - se bem que estas sejam mais frequentemente figuradas reclinadas, e não de pé. Além disso, segundo Leite de Vasconcelos (1905: 239-263), que viu os relevos quando ainda não era tão acentuada a sua degradação, a figura seguraria um cesto de frutos - iconografia que não é comum na representação de divindades aquáticas; o autor exclui expressamente a figuração de uma 
cornucópia. O busto que, em baixo-relevo, se representa no mesmo monumento, numa edícula em cujo frontão se vêem uma pomba e um martelo, figura ainda, possivelmente, o mesmo deus e não, como se tem proposto, o dedicante. Deve observar-se, porém, que, na edícula, a figura não é barbuda.

A Fonte do Ídolo (RODRÍGUEZ COLMENERO, 1987: 623-631) foi construída por Celicus Fronto, Arcobrigensis, Ambimogidus. Mas foi renovada por T(itus) Celicus Fronto, neto do anterior, e pelos filhos deste, $M$ (arcus) e L(ucius) (CIL II 2420). É possível que a figura de corpo inteiro corresponda a uma das fases e a edícula, a outra. Em ambas se poderá ter representado o deus Tongus. A ideia de que na edícula se representou o dedicante não parece aceitável, dados os elementos simbólicos do frontão. Na base da edícula, as letras ainda legíveis Front $[\ldots]$ não corresponderão ao antropónimo Fronto mas, eventualmente, a front [em] ou front [alia], aludindo à própria edícula ou a qualquer sorte de fachada, alpendre ou pórtico que o monumento teria. Assim, a inscrição deveria entender-se como Celicus fecit frontem. Segundo Leite de Vasconcelos, nunca teriam sido gravadas outras letras além de Front.

O famoso lintel do mausoléu emeritense em que se representam os rios Ana e Baraecus deve relacionar-se com o epíteto Anabaraecus de Reve e constitui elemento extralinguístico que reforça a interpretação de Reve como deus fluvial (PRÓSPER, 2002: 137-138).

São poucos e pouco significativos, como se vê, os elementos iconográficos de que dispomos para podermos confirmar as funções dos deuses que os linguistas, baseados nas etimologias, propõem (mesmo que, eventualmente, se possam considerar algumas estátuas do âmbito "castrejo", cujo significado é todavia duvidoso, vid. CALO LOURIDO, 1994: 693-725). No caso de Tongus Nabiacus, não é propriamente a iconografia que confirma a interpretação do deus como divindade aquática (ou genius loci de uma particular fonte) em desabono da interpretação que, baseada no airl. tongid, "jurar", tem feito de Tongus um deus que se invocaria como garante do cumprimento dos juramentos. É o contexto, isto é, a sua associação com uma fonte. 
Para além da iconografia dos deuses, há outros elementos extralinguísticos que devem ser tidos em conta quando se pretende testar a validade das propostas etimológicas. Adiante voltaremos ao assunto.

A lista das divindades indígenas do Ocidente peninsular, que numerosos achados epigráficos têm vindo a acrescentar, exigindo constantes aditamentos, começou, a certa altura, a ser limpa de falsos teónimos. Com efeito, o progresso dos estudos linguísticos conduziu a uma distinção nítida entre teónimos propriamente ditos e simples epítetos, estes últimos identificáveis pelos sufixos -aicus e similares, -brigus, -anus, -inus, -ius, -ensis. Assim, Bormanicus, Tameobrigus, Turiacus e muitos outros, que durante muito tempo se tomaram como nomes de deuses, são hoje considerados simples epítetos. Se, para quem invocava uma divindade só pelo epíteto (ou para quem, na época, lia a inscrição), era evidente a quem era o altar dedicado, é difícil hoje (e, na maior parte dos casos, impossível) identificar com segurança o deus invocado. A que divindades foram consagradas as aras a Bormanicus ou Turiacus? Seja como for, da lista inicial dos teónimos foram suprimidas muitas supostas divindades depois que se tomou consciência do carácter adjectival ou determinativo de vários nomes, e, por isso, da sua natureza de epítetos e não de teónimos. A obra de Blanca María Prósper é ainda, também sob este ponto de vista, digna do nosso crédito - sem esquecermos quantos outros, anteriormente, trabalharam para esta distinção entre teónimos e epítetos.

Alguns epítetos são claramente tópicos, isto é, correspondem a "apropriações", por uma comunidade local, de divindades de larga difusão. Assim, Bandi Longobricu(i) é, manifestamente, o deus Bandue adorado pelos habitantes de Longobriga (topónimo hoje representado por Longroiva, freguesia do concelho da Meda, Guarda); Durbedicus, primeiramente (e erroneamente) tomado como um deus, não passa de um epíteto de uma ignota divindade a quem os habitantes do castellum Durbede consagraram uma ara; Arantius Ocelaecus e Arantia Ocelaeca representam a invocação deste par divino pelos habitantes de um povoado Ocelum (que, para se distinguir de outros do mesmo nome, poderia ter um determinativo que não foi incluído nos epítetos daquelas divindades).

Noutros casos, porém, os epítetos referir-se-ão a uma qualidade ou função da divindade invocada. Bandiae Apolosego seria o Bandue/ 
Bandi "das vitórias" e Bandue Veigebreaego seria o Bandue/Bandi "dos cavalos" ou "do carro" (PRÓSPER, 2002: 260-261 e 259)?

Os deuses tinham (ou podiam ter) múltiplas qualidades e múltiplas funções. Este seu carácter multifário ou proteiforme explica a variedade dos epítetos que podem ser aplicados a uma mesma divindade. Alguns nomes podem corresponder a chamamentos que invocavam os deuses apelando para uma ou outra das suas funções, qualificações ou qualidades (BELAYCHE et alii, 2005). Corougia Vesuco, por exemplo, tem um epíteto que se regista na Gália e particularmente na Germânia aplicado a Mercúrio (OLMSTED, 1994: 330-331; JUFER e LUGINBUHL, 2001: 73 e 93). Se Vesucus deriva do IE *uesu-, Corougia Vesuco seria Crougiai, o Bom. Mas o mesmo deus Crougiai aparece noutros locais com outros epítetos: Toudadigoe, Munniaecus, Nilaicus, Magareaicus.

Não é fácil, para quem não tem preparação linguística (e, possivelmente, nalguns casos, mesmo para quem a tem), distinguir, relativamente a certos epítetos, se são tópicos ou se aludem a uma qualidade ou função. O sufixo -aico ou -ico, com o qual se forma um epíteto, de um topónimo (como em Durbedicus), serve também à formação de adjectivos que designam qualidades. Será o caso de Vorteaicus, Vordeaicus ou Vordiaecius, da raiz IE *werdh- ou *wert-, "alto" ou "volver, rodar" (PRÓSPER, 2002: 266). Da mesma raiz se terá derivado o adjectivo $\operatorname{Vord}(i)_{o}$, que surge numa ara encontrada em Sortelha (Sabugal, Guarda) - neste caso com segundo epíteto, Talaconius. O sufixo -ius, que se observa neste altar no qual o teónimo propriamente dito parece não vir expresso, também se encontra em Candamius, Candeberonius, Edovius, Vacocaburius, etc. O epíteto Vordeaicus repete-se em vários lugares, aplicado a Bandue/Bandi. Se $\operatorname{Vord}(i)$ o é também um epíteto, aplicar-se-ia ainda a Bandue/Bandi na ara de Sortelha?

\section{A equacionação de divindades com povos}

Sem nunca nos termos dedicado sistematicamente ao estudo das divindades indígenas do Ocidente peninsular, chamámos a atenção para a conveniência de tentarmos equacioná-las com populi ou etnias (ALARCÃO, 1988: 155-158). O primeiro estudo que publicámos com 
essa orientação (ALARCÃO, 1990) não tem interesse, hoje, senão para a história da historiografia, isto é, para quem quiser analisar como têm evoluído os estudos sobre as religiões indígenas peninsulares. Em 2001, porém, apresentámos noutro trabalho, que nos parece mais sustentável, as divindades que seriam as dos Lusitani.

Partiremos, para o estudo que agora apresentamos, da ideia de que, no Ocidente peninsular, havia, entre outras, duas grandes etnias, aparentadas, mas distintas: Lusitani e Callaeci.

Os autores gregos e latinos que falaram da conquista da Península Ibérica pelos Romanos ou descreveram a Hispania já conquistada aludem a ethnê (etnias), nationes (nações), gentes (gentes ou povos) e populi (povos). Estrabão, por exemplo, fala dos Lusitanos como a maior "etnia" da Península Ibérica (em III, 3, 3) e Plínio refere a gens Gallaica em VIII, 67, 166 (onde a distingue da gens Asturica) e a gens dos Lusitani em IV, 35, 116 (onde a menciona a par com os Celtici, Turduli e Vettones).

É legítimo interrogarmo-nos sobre se tais etnias ou gentes são, ou não, criações dos Romanos, sem qualquer correspondência com as identidades que as populações pré-romanas assumiriam.

Certas tribos da África ou das Américas foram inventadas pelos colonizadores europeus, pouco atentos às consciências émicas dos povos dominados, isto é, ao modo como os autóctones viviam ou sentiam as suas solidariedades e diferenças. Nuns casos, a invenção das tribos pelos colonizadores europeus correspondeu apenas a ignorância dessas unidades émicas; noutros, porém, tal invenção terá sido feita com cinismo; em algumas circunstâncias, sem consciência das más interpretações que se faziam das relações que os autóctones mantinham entre eles. Eventualmente, algumas tribos designadas e delimitadas pelos colonizadores poderão ter-se baseado em instáveis unidades políticas que circunstancialmente existiam no momento em que os colonizadores ocuparam as regiões em causa.

Sem qualquer pretensão de tratarmos teoricamente o problema das etnias e dos processos pelos quais elas emicamente se constituem, diremos que nos parece excessiva qualquer generalização sobre as etnias ou povos da Hispânia pré-romana sustentando que tais etnias foram criações dos Romanos. Pretendê-lo não é demonstrar o erro da tese contrária - isto é, da tese de que algumas etnias correspondem (ou podem 
corresponder) a populações com identidades próprias; é apenas contrapor à hipótese de que elas existiam, uma outra hipótese não confirmada: a de que as etnias mencionadas pelos autores antigos foram criações dos Romanos.

Acolhemos, por isso, com bastante reserva (o que não significa com absoluta discordância) afirmações como a de Edmondson (19921993: 27) que, por nos parecer claro exemplo da opinião por muitos partilhada, a seguir transcrevemos:

"In short, Roman generals and Greek intellectuals only remembered those ethnic names they wished to remember. They preferred to create for the sake of convenience a broad ethnic geography [o autor refere-se à vasta área entre o Tejo e o mar Cantábrico], caring little about the complex social and ethnic division among their opponents. Thus, the "Lusitanians", "Vettones", "Celtici", "Vaccaei" and so on were in large part a Greco-Roman geographical construct. These divisions, however, became the framework for the first conscious map of the region. In time the indigenous peoples of the region came to accept the ethnic identity imposed upon them by the Romans, and began to see their world in terms dictated to them by Roman generals and Greek intellectuals. The fact that these peoples often had to unite to resist Rome furthered the acceptance of these new terms of reference."

É verdade que autores gregos e latinos recordaram uns nomes e não outros, pois em vários textos se encontra a expressa declaração de que não se referem certos etnónimos por serem demasiadamente bárbaros ou corresponderem a povos pouco importantes (por exemplo, em Estrabão III, 3, 3). Mas a própria declaração implica o reconhecimento, por parte de quem declara, de que existiam povos com identidade e nomes próprios. Nalguns casos, os nomes foram incorrectamente reproduzidos: Plínio, IV, 34, 112 chamou Helleni a um povo cujo nome indígena poderá ter sido Aeleni, Aelani ou Eleni. Noutros casos, o nome poderá ter sido traduzido: o nome Amphilochi de Estrabão III, 4, 3, poderá corresponder ao de Ambimogidus que se encontra na Fonte do Ídolo 
(Braga). Se Ambimogidi significava "os que vivem de um lado e do outro (de um rio)", Estrabão (ou a fonte de que se serviu), tendo entendido o significado do nome indígena, tê-lo-á "traduzido" em vez de simplesmente o ter foneticamente reproduzido em caracteres gregos.

A omissão de certos etnónimos terá conduzido à abusiva extensão de alguns nomes étnicos para além (ou mesmo muito para além) das fronteiras que os povos pré-romanos, com seus nomes próprios, emicamente se reconheceriam. O caso dos Callaeci, examinado por A. Tranoy (1981: 65-66), é elucidativo: os primitivos (ou originais) Callaeci ficariam no extremo sudoeste da região de Entre Douro e Minho e os Romanos terão estendido o etnónimo a toda a vasta área do Noroeste que posteriormente integraria os conventus Bracarum e Lucensis.

As solidariedades e diferenças étnicas, emicamente reconhecidas, poderão ter sido reforçadas pela resistência aos conquistadores; mas não parece credível que tais solidariedades tenham sido criadas pelo próprio processo da resistência.

Não podemos, ingenuamente, tomar como correcto o "mapa" das etnias pré-romanas peninsulares que os autores antigos traçaram. Aliás, as informações de uns e outros nem sempre são coincidentes. Mas, embora reconhecendo que a etnia, como realidade cultural, é instável (faz-se e refaz-se na longa duração), julgamos abusivo, repetimos, considerar como puras ficções dos generais romanos, geógrafos e historiadores as etnias que encontramos mencionadas nos autores antigos.

\section{As divindades de Lusitani e Callaeci}

No artigo que publicámos em 2001 sobre os Lusitanos, tentámos identificar esta etnia e os seus limites a partir do mapa de distribuição de divindades que nos parecem ter sido suas próprias. Assumimos, claramente, um postulado metodológico: o de que a religião é (ou pode ser, ou pode ter sido na Idade do Ferro peninsular) um factor identitário importante, contribuindo para criar solidariedades e diferenças e para distinguir uma etnia, de outra com diferentes divindades; e que, por conseguinte, podemos recompor o mapa das etnias a partir da carta dos cultos.

Argumentar-se-á que a distribuição dos cultos indígenas, tal como a conhecemos, é a dos séculos I e II d.C., e que esta poderá não ter 
coincidência exacta com a distribuição original de época pré-romana. Não nos parece, porém, que o argumento condene, à partida, a investigação que pode fazer-se com base naquele postulado metodológico. Admitir que o mapa dos cultos indígenas daqueles séculos não tem qualquer correspondência com o mapa das divindades nos séculos I e II a.C. é apenas, mais uma vez, contrapor um postulado a outro postulado. E, contra-argumentando, diremos que os cultos são sempre fenómenos culturais de longa duração: as tradições religiosas são muito persistentes. Isto não exclui, evidentemente, a possibilidade (que metodologicamente devemos aceitar e, nalguns casos, parece confirmada) de um culto se ter estendido, na época romana, a uma área mais vasta do que a da sua original difusão. Por um lado, um culto pode ter sido levado de um lugar para outro, muito longe, por um emigrante. Por outro, nas áreas fronteiriças, que são, frequentemente, zonas de relações interculturais, com influências recíprocas de cultura material e de mentalidades entre dois povos, as divindades de um podem ter sido assimiladas por outro. Terá sido o caso da fronteira entre Lusitanos e Vetões. A este propósito, parece-nos muito sensata a distinção feita por J. C. Olivares Pedreño (2000-2001) entre deuses dos Vetões e deuses dos Lusitanos. Ch. Bonnaud (2002), estudando a religião dos Vetões, incluiu numa "Vetónia portuguesa" algumas divindades que considerou lusitanas. Pelo contrário, Ategina, Toga e Ilurbeda serão divindades dos Vetões, mesmo que se atestem alguns casos destes cultos em território que atribuímos aos Lusitanos pré-romanos.

O presente artigo, na linha de investigação do que dedicámos aos Lusitanos, alarga o estudo ao Noroeste peninsular. Assumindo, como hipótese de trabalho, que existiam no Ocidente peninsular duas grandes etnias, a dos Lusitani e a dos Callaeci, vamos procurar identificar as suas divindades e as funções que teriam.

Os Callaeci a que aqui nos referimos não são aquele suposto populus que ocuparia o extremo sudoeste da região de Entre Douro e Minho, com capital em Cale (Porto). São todos aqueles populi que, na sua maioria mencionados por Plínio, Ptolemeu e Estrabão, ocupavam a região que os Romanos viriam a integrar nos conventus Bracarum e Lucensis (TRANOY, 1981: 53-74). Como veremos pela análise da difusão geográfica dos cultos, é possível que esta etnia se estendesse, a 
sul do Douro, até à serra da Estrela e ao rio Vouga. Talvez ocupasse ainda a parte ocidental da área que os Romanos integraram no conventus Asturum. Se, ao conquistarem toda esta região, os Romanos chamaram Callaeci ao conjunto dos populi que ocupavam essa área, esses populi não se dariam a eles mesmos tal nome colectivo. Se acaso tinham um nome para a sua etnia (o que nos parece possível), ignoramos tal nome. A etnia poderia ser a que Avieno, Ora Maritima, 195 menciona como os Saefes, o "povo das serpentes". Mas não temos argumentos suficientes para sustentar que a designação é indígena. Se a etnia assim se chamava a ela mesma, o nome terá desaparecido, pois é mais do que duvidoso que seja reminiscência dele o nome do Lar Sefius adorado em Adaúfe (Braga) (PRÓSPER, 2002: 317).

Procuraremos entender ou explicar os deuses ensaiando uma perspectiva funcionalista e comparativista.

$\mathrm{O}$ nosso funcionalismo assenta num postulado: o de que as religiões (ou os deuses) servem para explicar o mundo e regular as actividades dos homens e as suas relações sociais. Não seguimos o trifuncionalismo dumeziliano, por nos parecer inaplicável às sociedades lusitana e galaica do Bronze Final e da Idade do Ferro.

Todas as religiões contêm uma cosmogonia, isto é, uma explicação para a origem do mundo e da humanidade. De um modo geral, os "deuses" que criaram o mundo não foram propriamente objecto de culto. Figuravam em relatos que se transmitiam oralmente e que algumas literaturas, como a grega ou a védica, registaram. Quando não dispomos de fontes escritas, não podemos, porém, conhecer as cosmogonias antigas.

Os "deuses" que criaram o mundo cederam o lugar aos deuses que passaram a governá-lo. Na Grécia, Geia e Úrano, Crono e Reia não tinham lugar senão na cosmogonia.

Os deuses que governavam o mundo e os homens tinham, porém, ainda uma função explicativa: Zeus explicava as trovoadas e as chuvas; Perséfone, o renascer da Natureza na Primavera (aliás, integrada numa história na qual também eram actores Deméter e Hades).

Havia ainda deuses para protegerem o lar ou os pastores, deuses que se invocavam para garantir o êxito das colheitas ou dos combates, deuses que favoreciam os artífices ou os mercadores, etc. 
Partindo da perspectiva de que os deuses regulamentavam as relações sociais e as actividades quotidianas, temos de perguntar-nos o que fazia cada uma das divindades lusitanas e galaicas. Na total ignorância dos mitos, que seriam a melhor forma de entendermos as funções dos deuses, a análise linguística dos teónimos é fundamental. Mas aqui regressamos à justa observação de F. Villar: as análises linguísticas da teonímia têm de ser testadas por elementos extralinguísticos.

Definindo o panteão de uma etnia, temos de reconstituir nele os deuses necessários à explicação do funcionamento da Natureza e à regulamentação das relações sociais e das actividades quotidianas; correlativamente, não podemos duplicar funções. Dito por outras palavras, devemos acolher com reservas as análises linguísticas que, num mesmo panteão, propõem demasiados deuses da guerra ou demasiadas divindades aquáticas, ao mesmo tempo que não restituem deuses para actividades fundamentais da etnia considerada. Daí decorre também o interesse em tentar equacionar os deuses com etnias. Sem esse esforço, nunca tomaremos consciência dos deuses que faltam ou das divindades que, por repetição de funções, são desnecessárias.

A nossa perspectiva será, ao mesmo tempo, comparativista. Sendo Indo-Europeus os Lusitanos e os Calaicos, alguma correspondência deve existir com outras religiões indo-europeias. As religiões ditas célticas não serão mais importantes do que a grega ou a romana para efeito desta comparação que nos parece útil ou necessária. Não nos referimos à religião grega da época clássica ou à religião romana dos fins da época republicana ou dos inícios do Império. Referimo-nos aos estádios arcaicos dessas religiões, quando o Hermes helénico não era ainda exactamente o que viria a ser na época clássica, ou quando o Neptuno romano era deus das águas em geral e não apenas do mar, ou ainda quando Marte não era invocado só como deus da guerra, mas como deus dos agricultores - neste último caso, tal como nos aparece em Catão, De agricultura, 141 .

Dêmos exemplos, para melhor nos fazermos entender:

$\mathrm{Se}$ em todas as religiões indo-europeias encontramos uma divindade que tem o reino dos céus, que deus dos Lusitanos e Calaicos teria essa função? Seria Bandue/Bandi? Em tal caso, não será mais 
correcta a etimologia proposta por Rosa Pedrero (2000) do que a sugerida por Blanca María Prósper (2002)? Se em todas as religiões indoeuropeias temos uma divindade que explica o renascer da Natureza na Primavera, que divindade teriam os Lusitanos e os Calaicos para cumprir essa função? Seria Nabia?

Estará condenado ao insucesso um ensaio como o que propomos? Será que é um ínvio caminho o que pretendemos seguir? A extrema variedade e multiplicidade dos deuses do Ocidente peninsular será um labirinto de onde não sabemos sair por não termos fio de Ariadne? Ou será que fomos nós, pelos nossos equívocos, que fizemos da religião de Lusitanos e Calaicos uma "floresta de enganos"? Descobriremos a chave que nos abra a porta para entendermos as religiões indígenas do Ocidente peninsular?

Talvez os deuses, afinal, não sejam tantos quantos a variedade dos teónimos e dos epítetos à primeira vista sugere. Primeiro, porque muitos teónimos, como vimos, não são verdadeiros teónimos, mas simples epítetos. A epiclese, isto é, a invocação de um mesmo deus por vários nomes é fenómeno conhecido e estudado (BELAYCHE et alii, 2005). Segundo, porque muitos dos deuses não são verdadeiros deuses, mas simples genii loci que protegiam ou tinham morada neste particular monte ou rio, neste concreto vale ou lago, nesta portela entre montes, neste vau de rio, nesta fonte.

Devemos, pois, começar por distinguir teónimos, de epítetos. E, logo de seguida, distinguir os deuses, dos genii, atribuindo àquela primeira categoria (a de deuses) os que se atestam com o mesmo nome (ainda que com diferentes epítetos) em lugares diversos e distantes; e à segunda (a de genii loci), os que estão atestados por inscrições únicas (ou, quando múltiplas, por inscrições achadas todas num mesmo local). Bandue/Bandi, Reve e Nabia, Arentius/Arentia, Quangeius, Trebarune, Crougiai e Cossue/Coso entram na primeira categoria. Na segunda temos multidão: uns são fáceis de identificar porque seus nomes vão precedidos dos nomes genius, lar, juno, munidi, tutela; outros, sem essa expressa identificação, não deixam de ser genii. A multidão de genii é fácil de entender para quem esteja familiarizado com a religião romana: uma cidade tinha génio que a protegia; mas, nessa mesma cidade, um génio protegia o forum ou a basílica (como o Genius Baselicae de Aeminium); 
um outro génio protegia o mercado (como o Genius Macellum de Bracara Augusta); génios ou lares moravam nas ruas.

As divindades Bandue/Bandi, Reve e Nabia, que os Lusitanos adoravam, encontram-se também amplamente testemunhadas no Noroeste, isto é, num território que não podemos atribuir aos Lusitanos porque as fontes antigas são consistentes em referir, no extremo noroeste da Península Ibérica, os Calaicos.

Por outro lado, não encontramos, no território dos Calaicos, os deuses Arentius/Arentia, Quangeius e Trebarune, atestados no território dos Lusitanos. Mas achamos, no Noroeste, os deuses Cossue/Coso e Crougiai, que não se registam na área que definimos como própria dos Lusitanos.

Se Lusitanos e Calaicos eram duas etnias distintas mas aparentadas, teriam, como elemento que as aparentava, os cultos de Bandue/Bandi, Reve e Nabia? E, como elemento que as distinguia, teriam os Lusitanos os cultos de Arentius/Arentia, Quangeius e Trebarune, e os Calaicos os cultos de Cossue/Coso e Crougiai?

Aos deuses comuns aos Lusitanos e Calaicos chamaremos supranacionais; às divindades que, observadas no território de uma destas etnias, não se encontram no da outra, chamaremos nacionais. As designações que adoptamos pressupõem, naturalmente, que chamamos "nação" ao que os Gregos designavam por ethnê e os Romanos, por gens. Mas as designações de supra-étnicas e gentias parecem-nos em demasia arrevesadas. Ao cabo e ao resto, a designação de natio também se encontra em escritores latinos - embora mais para referir uma pertença territorial do que uma integração étnica (RODRÍGUEZ, 1996). Não vale a pena batalhar, porém, sobre o que é de nímia importância. Em vez da designação "supranacionais", podemos usar "divindades comuns a Lusitanos e Calaicos". Mais ajustados nomes não nos ocorrem.

\section{Divindades supranacionais}

BANDUE/BANDI

As dificuldades de restituição do tema morfológico deste teónimo não foram ainda cabalmente resolvidas. Alguns autores optam por referir-se a Bande; outros, a Band-. 
A ideia de que Bandue/Bandi não é um deus particular e de que, no suposto teónimo, devemos ver apenas um nome comum equivalente ao latino deus (SILVA, 1986: 295-296; HOZ, 1986) não parece aceitável.

A etimologia do nome continua a suscitar as maiores dúvidas, com desencontradas propostas (PRÓSPER, 2002: 269-276, com o estado da questão e mais uma hipótese, aliás nada convincente).

Este é um caso em que a análise linguística deve ir a par com considerações extralinguísticas, mesmo assumindo os riscos (mas também as vantagens) de uma circularidade hermenêutica que só por má-fé se poderá apelidar de petição de princípio.

Se considerarmos que as divindades supranacionais de Lusitanos e Calaicos são Bandue/Bandi, Reve e Nabia; se tivermos em conta que, sendo indo-europeia a religião daquelas etnias, devemos encontrar alguma equivalência com outros panteões indo-europeus; se pensarmos que em todas as religiões indo-europeias existe um deus que domina o reino celeste; se, finalmente, reconhecermos que a função celestial não cabe (como adiante veremos) nem a Reve nem a Nabia - não poderemos deixar de pôr a hipótese de Bandue/Bandi ser o deus do panteão lusitanocalaico correspondente ao Zeus grego e ao Júpiter romano.

Contra esta ideia não vão as propostas de Rosa Pedrero (2000) ou Carlos Búa (2000). A primeira, depois de se ter inclinado para um étimo indo-europeu *bhendh-, que significaria "atar, manter unido, vincular" (PEDRERO, 1999), opta agora por um composto de ban + *deiw-. Este último elemento significaria "celeste". Ban-, anteposto a um nome masculino, serve, no airl., para transformar esse nome no seu correspondente feminino. Esta interpretação suscita dúvidas, dado o carácter masculino da divindade. Mas, ainda segundo Rosa Pedrero, benn- significa, em airl., "cimo ou cume de um monte" e bann-, em bretão, "eminência ou altura". Quanto a Carlos Búa, estabelece relação entre o teónimo e o airl. bhandate, "resplandecer"- o que, naturalmente, logo nos recorda o Sol.

Pela nossa parte, não podendo participar na discussão linguística, só nos resta convidar os linguistas a reexaminarem a questão assumindo, como hipótese, o carácter celestial de Bandue/Bandi.

Não se opõem a esta hipótese os epítetos do deus, Brialeacus, Malunaicus, Verubricus se, como pretende Blanca María Prósper (2002: 259-263), significam "o das alturas" ou "o superior". Outro epíteto, 
Vordeaicus, se derivado do IE *werdh-, "alto", significará ainda "o das alturas". Tais nomes equivaleriam aos epítetos Maximus, Supremus, Summus, dados a Júpiter.

Se outros epítetos fazem deste deus o protector de certas povoações (Longobricus, Araugelensis, etc.), alguns nomes parecem ainda reportar-se a qualidades: Apolosecus, por exemplo, significaria “ o das rápidas vitórias" (PRÓSPER, 2002: 260).

A ara a Bandua Horrico do museu de Alenquer (DIAS, 2001: 2628), sem proveniência exacta conhecida, parece ter sido gravada em calcário liós da região. Sendo assim, seria um exemplo de culto a esta divindade fora da área original de Lusitanos e Calaicos.

\section{REVE}

O deus Reve, adorado por Lusitanos e Calaicos, era, segundo F. Villar (1996), uma divindade aquática ou até, mais especificamente, um deus dos rios. Poderia corresponder ao Neptuno romano primitivo, que não era deus dos mares mas, mais genericamente, deus de todas as águas.

A objecção que pode levantar-se a esta interpretação deriva de dois epítetos com que Reve foi adorado em território de Calaicos: Laraucus (numa ara de Baltar, Orense e numa outra de Vilar de Perdizes, Montalegre, Vila Real) e Marandicus (em Guiães, Vila Real, vid. RODRÍGUEZ COLMENERO, 1999: 106). Os dois nomes mantêm-se nas formas actuais de Larouco e Marão, que correspondem a duas das maiores serras do norte de Portugal. O de Marandicus, excluído o sufixo -icus, revela um nome Marand- ou Marant- que está na origem do topónimo Amarante, cidade que fica nas faldas do Marão.

Larauc- e Marand- poderiam ser, inicialmente, corónimos e não orónimos? Na sua origem seriam nomes de regiões e não de serras? Haveria, assim, uma região chamada Laraucum e outra denominada Marant-e Reve Laraucus e Reve Marandicus seriam os deuses das águas dessas regiões? Recordaremos que o Índrah védico era o deus que libertava e fazia correr as águas das montanhas (OLMSTED, 1994: 66-67).

Se, argumentando que Lusitanos e Calaicos, sendo indo-europeus, deviam adorar, como os outros povos da mesma estirpe, um deus celestial 
e um deus das águas, não podemos omitir uma perplexidade. Nas religiões indo-europeias existe normalmente um deus subterrâneo. Ora não vemos esse deus na religião comum daquelas duas etnias, visto não podermos reconhecê-lo em Nabia, por ser divindade feminina.

\section{NABIA}

Para Blanca María Prósper (2002: 194), Nabia significa “o vale". Diríamos que nos parece mais adequado fazer de Nabia "a (senhora) do vale" ou "a que mora no vale". Ora, pensando que o renascer da Primavera era fenómeno que não podia deixar de surpreender e de ser objecto de uma explicação mítica, e, por outro lado, que é nos vales que o renascimento primeiro ocorre, não corresponderá Nabia à Perséfone grega, a "menina do trigo"? Sob uma forma ou outra, e com diferentes nomes, semelhante deusa encontra-se em muitas religiões indoeuropeias: é a Prosérpina romana, talvez a Nantosvelta da Gália.

Nantosvelta significará "o vale que o sol aquece" ou "a que faz florir o vale" (OLMSTED, 1994: 42). Se aceitarmos esta etimologia, teremos nesta deusa correspondência com Nabia. Mas, porque as correspondências raramente serão exactas, a deusa Nabia não parece ter par masculino, enquanto Nantosvelta, na Gália, acompanha Sucellus. Este deus, que se representa com um martelo na mão e acompanhado por um cão, seria um deus da região subterrânea (OLMSTED, 1994: 42 e 300-302). Não podemos deixar de pensar no Tongus Nabiacus da Fonte do Ídolo (Braga), tanto mais que, aqui, o que parece ser um busto do deus se apresenta, como vimos, numa edícula em cujo frontão se representam um martelo e uma pomba.

Os símbolos, porém, são polissémicos. Não podemos, sem reservas, sustentar que o martelo, que acompanha Plutão e Vulcano, identifica Tongus com uma divindade subterrânea. Mais parece, como vimos atrás, que Tongus será um deus (ou génio) das fontes.

Quanto ao epíteto Nabiacus, tanto podemos considerá-lo derivado do nome comum nabia, "o vale" (e neste caso Tongus Nabiacus seria o "Tongus do vale"), como ver no epíteto uma alusão à deusa Nabia (caso em que Tongus Nabiacus seria "o Tongus de Nabia", com o sentido de "acompanhante de Nabia"). 
A inscrição de Marecos (Penafiel, Porto), que alude a um sacrifício consagrado a Nabia Corona, "ninfa" (ou divindade protectora) dos Danigi, e a outras divindades, recorda uma cerimónia realizada em 9 de Abril. Ora, não ficando esta data distante da que hoje consideramos a do equinócio da Primavera, poderemos tomar a inscrição de Marecos como argumento a favor da função que atribuímos a Nabia?

$\mathrm{Na}$ ara de Marecos, P. Le Roux e A. Tranoy (1974) leram primeiro: O(ptimae) V(irgini) Co(nservatrici), vel Co(rnigera), et Nim(phae) Danigom Nabiae Coronae. Depois, P. Le Roux (1994: 561) sugeriu O(mnia) v(ota) co(nsagro) et nim(bifero) Danigo m(acto) Nabiae Coronae, traduzindo: "Consagro-vos todas estas oferendas e, por Danigo, que dispensa a chuva, sacrifico a Nabia Corona".

A primeira restituição, "À excelente virgem conservadora (ou cornuda) e ninfa dos Danigos", parece-nos preferível.

A inscrição começaria pela invocação da divindade, com seus epítetos. Segue-se a indicação dos animais oferecidos: à própria deusa Nabia (agora nomeada sem epítetos), a Júpiter, a uma outra divindade [...]urgo e a Ida (ou Lida). Estando atestado o epíteto Idunica ou Idennica com o sentido de "a que gera ou dá à luz" (OLMSTED, 1994: 157), esta divindade a que se oferece um cordeiro seria, talvez, deusa que se invocaria para favorecer o parto dos animais. Na inscrição, os animais oferecidos parecem preceder os teónimos.

Perséfone é por vezes, na Grécia, designada apenas como Korê, "virgem" ou "rapariga". Não surpreende, pois, que Nabia leve este nome de "virgem" na ara de Marecos.

\section{Divindades específicas dos Lusitanos}

\section{ARENTIUS/ARENTIA}

Arentius e Arentia parecem ser divindades dos Lusitani sem correspondência com divindades específicas dos Callaeci.

Arentius, na interpretação de Blanca María Prósper, relacionar-se-ia com o hidrónimo Arent-/ Arant-, cuja raiz significaria "correr, pôr-se em movimento"(PRÓSPER, 2002: 99). Ora, salvo melhor interpretação dos linguistas, talvez se possa sustentar que, a partir de um tema verbal com o sentido de "correr", se formaram hidrónimos 
(porque os rios correm) mas, por outro lado, um teónimo que significaria "o que corre" mas nada teria a ver com água corrente.

Que os Lusitanos adorassem uma divindade que corria ou favorecia quem corresse nada tem de surpreendente. Com efeito, os autores antigos que se referiram aos Lusitanos são consistentes na informação de que a rapidez com que eles atacavam ou fugiam explica muitos dos seus êxitos na guerra que tão longamente sustentaram contra os Romanos. Observaremos ainda que o adjectivo pernix, "ágil", com que Avieno (Ora Maritima, 196) qualifica os Lusitani parece aludir à rapidez com que se deslocavam. Por outro lado, nenhuma informação semelhante temos a propósito dos Callaeci, que não fariam correrias semelhantes às dos Lusitani. Nesta perspectiva, poderá entender-se por que motivo não temos, entre os Callaeci, divindade homóloga do Arentius lusitano.

Se Arentius era uma divindade invocada pelos latrones lusitanos, não é forçoso considerar que se trata de um deus essencialmente ou exclusivamente guerreiro. Poderia, na sua origem, ser uma divindade plurifuncional. A história poderá ter acentuado a sua função guerreira. Um século de intrépida guerra contra os Romanos, durante o qual o deus Arentius terá sido invocado na rapidez das guerrilhas e no estrépito das batalhas campais, pode ter acentuado o que inicialmente seria apenas uma das funções da divindade.

Talvez, concluída a guerra e pacificada a área, a função guerreira de Arentius tenha minguado, enquanto outras funções originais terão adquirido nova vida. Ou o deus terá passado a ser venerado como o que garantiria o êxito nos mais variados sucedimentos da vida pessoal ou comunitária. Mas os epítetos não são elucidativos. No Ferro (Covilhã, Castelo Branco), Arentius é invocado como Ocelaicus (e na mesma ara, venera-se Arentia Ocelaica). Numa ara recolhida em Castelejo (Fundão, Castelo Branco), a dedicatória é feita Arantiae et Arantio Eburobricis (SALVADO, ROSA e GUERRA, 2004). Na Tapada da Ordem (Idanhaa-Nova, Castelo Branco), Arentius leva o epíteto de Tanginiciaicus. É possível que uma linhagem, remontando sua origem a um Tanginus, se chamasse Tanginici. Sobre este nominativo plural, por nova sufixação, ter-se-ia formado o epíteto Tanginiciaicus. No Sabugal (Guarda), Arentia leva também uma dupla sufixação: Equotullaicensis. Em Zebras 
(Fundão, Castelo Branco), o epíteto de Arentius é Cronisensis. Não é segura, porém, esta leitura (GUERRA, 1998: 150 e 420-421). Se acaso se devesse restituir $C($ o)ronisensis, o epíteto poderia igualmente relacionar-se com uma linhagem que se considerasse descendente de um Coronus. A ara, aliás, foi achada no que parece ter sido o impluvium de uma villa, onde um altar a Arentius como protector de uma linhagem teria perfeito lugar. Na mesma freguesia de Zebras, uma Aranta, filha de Craesonis ou Craesonus (Atlas), dedicou uma lápide funerária ao sogro. Mas não parece que possa restituir-se Craesonisensis onde vários autores, embora com dúvidas, têm lido Cronisensis.

Os epítetos referidos parecem indicar que, na época romana, Arentius e Arentia eram invocados como protectores de povoados e, eventualmente, também de linhagens.

Os Romanos poderão ter identificado Arentius com o seu deus Marte. Estrabão, III, 3, 7, diz que os "montanheses" sacrificavam a Ares um bode, prisioneiros de guerra e cavalos. Mas não é claro se os "montanheses" eram os Lusitanos ou os Calaicos e Ástures (ou todos estes povos).

Arentius tinha, como parceira, Arentia. Sem querermos valorizar em demasia o epíteto Equotulaicensis (de ekwo, "cavalo") com que Arentia foi adorada no Sabugal (Guarda), não deixaremos de perguntarnos se esta divindade não era, também, protectora dos guerreiros, ou, mais especificamente, dos cavaleiros.

Se devemos equacionar Arentia com a deusa Epona que foi adorada sobretudo na Gália, é problema melindroso. Se a deusa Iconna, presente na inscrição de Cabeço das Fráguas, se equaciona com Epona (PRÓSPER, 2002: 51-53), e esta, por seu turno, com Arentia, teríamos, entre os Lusitanos, duas divindades (Iconna e Arentia) com a mesma função. Isso parece dificilmente aceitável. Ou deveremos considerar que, sendo Iconna equivalente a Epona, era uma antiga deusa equina indo-europeia da fertilidade (PRÓSPER, 2002: 53), mas sem relação com Arentia?

É ambíguo, porém, o significado, na área actualmente portuguesa do antigo território dos Lusitanos, das numerosas aras a Marte e a Vitória. Terão Arentius e Arentia sido identificados com aquelas divindades romanas? Mesmo que o tenham sido, Marte e Vitória seriam adorados como divindades militares? Marte, como vimos, também foi invocado pelos agricultores (CATÃO, De agricultura, 141, 2; DUMÉZIL, 1958: 51). 


\section{QUANGEIUS}

O nome do deus Quangeius estará relacionado, segundo F. Villar e Blanca María Prósper (2002: 310), com o IE *kuwon, "cão". Ora, sendo este animal um excelente companheiro e guia dos caminhantes, não poderemos fazer de Quangeius um deus com funções similares às do Hermes grego primitivo?

Esta última divindade era um deus dos caminhos e dos mensageiros, divindade protectora dos pastores e acompanhante dos mortos ao outro mundo (VERNANT, 1971: 126-128; FRISK, 1960: 563564; OLMSTED, 1994: 138-139).

Um Quangeius Tanngus, venerado em Nisa (Portalegre), se acaso a leitura correcta do epíteto fosse Tanaico (PRÓSPER, 2002: 309), confirmaria o carácter de Quangeius como acompanhante dos mortos. Infelizmente, esta reinterpretação não se acha confirmada.

A maior parte das aras consagradas a Quangeius encontra-se no território que atribuímos aos Lusitanos (ALARCÃO, 2001).

Um Quangeius Turicaecus, possivelmente invocado numa povoação *Tur-iko (PRÓSPER, 2002: 309), acha-se documentado numa ara que foi vista num antiquário de Borba (Évora). É duvidosa a integração desta área no território dos Lusitanos pré-romanos. Mas a proveniência da inscrição também é incerta, pois o antiquário que a tinha à venda em Borba pode tê-la trazido de lugar distante.

Opõe-se à nossa definição de Quangeius como divindade especificamente lusitana o testemunho da ara encontrada em Servoy (Verín, Orense). Tratar-se-á, como no caso da Triborunni de Cascais (ENCARNAÇÃO, 1985), de ara posta por emigrante procedente da Beira Baixa ou de outro lugar do antigo território dos Lusitanos? O nome do dedicante, Gaius Iul(ius) Severinu(s), é demasiadamente atípico para podermos viabilizar a hipótese. Mas manteremos Quangeius como divindade específica dos Lusitanos enquanto outras inscrições não contradisserem, de maneira inequívoca, o que sustentamos. Os que eventualmente argumentarem que não podemos reconstituir a área original de um determinado culto, porque os testemunhos de que dispomos são de uma época em que a área de difusão poderá não corresponder à primitiva, não estão autorizados a argumentar agora, com 
pau de dois bicos, que a ara de Verín destrói a hipótese de Quangeius como divindade lusitana.

\section{TREBARUNE}

O nome, por muitos autores e durante muito tempo segmentado em Trebo-/Treba- (da raiz IE treb-, "casa, habitação"), e -runa (com o sentido de "segredo"), foi interpretado como significando o "segredo da casa". "Segredo" poderia estar aqui no sentido de intimidade, privacidade, tranquilidade. Trebarune foi, assim, interpretada como uma deusa do lar, que seria homóloga da Héstia grega.

Blanca María Prósper (2002: 47-49), aliás seguindo uma proposta de Schmoll, segmentou o teónimo desta forma: Treb-arune. Admitindo uma relação do elemento -arune com *Arawn= Araunus (que Vielle, citado por Prósper, interpretou como "o que favorece ou protege"), observou, porém, que uma forma aruna está na base de hidrónimos europeus; e por isso propôs, como sentido de Trebarune, "o rio da aldeia".

A quem, como nós, falta competência linguística, é difícil optar por uma interpretação de Trebarune como deusa do lar ou como divindade aquática. Mas não deixaremos de observar que a primeira interpretação, fazendo de Trebarune uma divindade similar à Héstia grega, ilumina de maneira completamente diferente a religião dos Lusitanos. Se Arentius e Trebarune são divindades aquáticas (às quais, aliás, deveríamos somar muitas outras consideradas também aquáticas por Blanca María Prósper), porquê tantas divindades relacionadas com a água? Se, pelo contrário, interpretarmos Arentius como "o que corre" e fizermos dele um deus protector dos latrones lusitanos nas suas correrias, e se considerarmos Trebarune como uma deusa protectora do lar que os latrones deixariam desprotegido nas suas ausências, o panteão lusitano, dispensadas tautologias aquáticas, ganha uma entendível ou explicável funcionalidade.

A estas duas divindades, Arentius e Trebarune, poderiam aplicarse muitas das judiciosas observações que J. P. Vernant (1971: 124-170) fez a propósito das divindades gregas Hermes e Héstia. 


\section{Divindades específicas dos Calaicos}

As divindades que encontramos entre os Calaicos mas não se observam no território que definimos como o dos Lusitanos pré-romanos são Crougiai e Cossue/Coso.

\section{CROUGIAI}

O deus Crougiai, em cujo nome se encontra a raiz IE *kreuk-, que significa "colina, monte ou montão" (PRÓSPER, 2002: 185), seria "o (senhor) do(s) monte(s)" ou "o que mora no(s) monte(s)". Os epítetos com que nos surge demonstram que se trata de divindade masculina, não feminina.

Poderíamos admitir que os Callaeci contrapunham, ao espaço "domesticado" dos povoados e das terras de ao redor dos castros, o espaço hirsuto dos bosques e matos e o espaço deserto de montes calvos ou fragosos. Crougiai poderia ser o deus do espaço selvagem, contraposto a Cossue/Coso, o deus que protegeria os povoados.

Talvez esta hipótese não deva ser liminarmente rejeitada. Mas contra ela temos o argumento de que não encontramos divindade masculina semelhante noutras religiões indo-europeias, excepto no Silvanus romano, que foi, todavia, divindade secundária.

Corrigindo (ou revendo) a hipótese, podemos considerar que o espaço "selvagem" não era improdutivo: era o pasto de cabras e ovelhas, o bosque de carvalhos onde se recolhia a bolota que, triturada, dava a farinha de que os montanheses faziam pão (ESTRABÃO, III. 3, 7). Talvez o espaço "selvagem" fosse ainda terreno que, por desmatação e queima, desse terras para cultura de cereais. Crongiai, "o senhor dos montes", poderia ser, assim, um deus que protegia agricultores e pastores, isto é, um Marte agrícola e pastoril. Criador dos montes, Crougiai poderia ser o deus que havia ensinado os Callaeci a viver neles, explorando seus recursos?

A pouca convicção com que avançamos estas hipóteses leva-nos, porém, a tentar outras interpretações.

Voltando à raiz *kreuk-, poderia, segundo Blanca María Prósper, significar "montão". Ora S. Martinho de Dume, em De correctione rusticorum, 7, escreveu: 
"Um outro demónio quis chamar-se Mercúrio, que foi o inventor dos roubos e das fraudes dolosas, a quem os homens cobiçosos, como se fosse ao deus lucro, oferecem sacrifícios, ao passarem pelas encruzilhadas, lançando pedras e com elas formando montes."

Noutro passo, De correctione rusticorum, 16, o santo dumiense refere-se às velas que se acendiam" junto às pedras".

Se S. Martinho de Dume escreveu no séc. VI d. C., refere-se todavia a práticas ancestrais que o Cristianismo ainda não conseguira extirpar. Teriam os Calaicos um deus que se venerava em montões de pedras, os quais iam crescendo porque cada um lhe arremessava (ou nele depositava) mais uma? Seria Crougiai essa divindade? Deveremos aproximar Crougiai de Mercúrio, ressalvando que não seria esse Mercúrio que S. Martinho toma por deus dos roubos, das fraudes e dos homens cobiçosos, mas um Mercúrio mais conforme ao Hermes arcaico do qual falámos a propósito de Quangeius?

Na Gália, Mercúrio tinha relação com montes (OLMSTED, 1994: 316-318). Na mesma província e, sobretudo, na Germânia, o mesmo deus recebeu o epíteto de Visucius e Vesucus (OLMSTED, 1994: 330331: JUFER e LUGINBUHL, 2001: 73 e 93). Ora numa inscrição de Minhotães (Barcelos, Braga), Crougiai (escrito Corougiai) leva o epíteto de Vesuco. Será que o epíteto deriva do IE *uesu-, "bom" e deve tomarse como variante gráfico-fonética de Visucius ou Vesucus? Segundo Blanca María Prósper (2002: 183), Vesuco, porém, derivaria de IE *weis, "fluir, desfazer-se".

Desviando-nos, por momentos, da directa linha do nosso raciocínio, não deixaremos de manifestar algumas dúvidas quanto à leitura que tem sido feita desta inscrição de Minhotães: Arcuius aram pos[u]it pro vo[t]o dom(i)n[o] Corougia[e] Vesuco in servis ib[i] et ubicu $[\mathrm{m}]$ terrarum. Tem-se entendido assim o texto: "Arcuius esta ara colocou, em razão do voto, ao senhor Corougia Vesucus, (favorável) aos escravos aqui e em toda a parte" (R.L., L.S.: 373).

Parece difícil aceitar esta interpretação, por anacrónica. Quem, escravo, liberto ou homem livre, iria pedir a intercessão do deus a favor dos escravos de todo o mundo? Não haveria, na época, semelhante filantropia ou espírito de classe que o texto, assim interpretado, implica. 
Perguntamo-nos se, onde se leu Vesuco in servis et ubicum terrarum, não deverá imaginar-se Vesuco [Co]nserv [atori] istic (com / i/ incuso) et ubicum terrarum. O lapicida, tendo escrito Vesuco, terá sido confundido pela repetição das duas últimas letras do nome nas duas primeiras de um suposto Conserv(atori).

Seja como for, pouco ou nada podemos retirar do epíteto Vesucus, para além de este indicar uma divindade benfazeja - o que, como é óbvio, não nos faz avançar no entendimento das funções da divindade.

$\mathrm{Na}$ famosa inscrição rupestre, em língua lusitana, de Lamas de Moledo, Crougiai leva o epíteto de Magareaicoi. É duvidoso se temos aqui um étnico menor - Macarii - ou uma referência toponímica. Fica perto a serra ainda hoje chamada de S. Macário. E J.L. Inês Vaz (1997: 191) chamou a atenção para o nome do castro vizinho chamado da Maga.

Numa ara de Mosteiro da Ribeira (Ginzo de Limia, Orense), Crougiai é chamado Toudadigoe. Se este nome se relaciona com IE *teuta, "povo" (PRÓSPER, 2002: 181-183), Crougiai foi adorado como divindade protectora de um povoado ou da população de uma região?

Esta última inscrição conduz-nos a uma derradeira hipótese, que não deixaremos de apontar, ainda que se nos não afigure mais convincente do que as anteriores.

Se os Lusitani se estabeleceram numa área provavelmente pouco povoada (ALARCÃO, 2001:324-325), os Callaeci, por seu turno, parece terem-se fixado numa região com um substrato populacional considerável. Este(s) povo(s) pré-existentes viveriam em aldeias ou granjas situadas em vales ou a meia-encosta, não protegidas por muralhas. Os Callaeci estabeleceram-se no alto dos montes, em castros que rodearam de muralhas. Talvez a mítica invasão de serpentes a que a Ora Maritima se refere conserve memória dessa invasão. Será que os Callaeci se definiriam como "o povo das montanhas", por oposição aos autóctones que viveriam em espaços menos altos? Correlativamente, a população invadida olharia para os novos habitantes também como "o povo das montanhas"? E, em tal caso, seria Crougiai ("o senhor dos montes") uma divindade que protegeria a etnia dos Callaeci na sua globalidade? A etnia, obviamente, não se definiria só por esse traço que era o da sua instalação no alto dos montes; mas este poderia ser importante na definição da sua identidade. Os Callaeci adorariam então, 
como divindade nacional, um deus que, protector da sua etnia e garante da sua identidade e solidariedade, de algum modo estaria relacionado com a montanha, que era o seu habitat.

Estrabão, III, 3, 7 diz que os "montanheses" (refere-se aos Calaicos e Ástures) precipitavam os prisioneiros do alto das montanhas e que infligiam o suplício da lapidação aos parricidas, mas, neste caso, longe dos montes e dos rios. Ora a morte dos prisioneiros era, possivelmente, sacrifício a algum deus; e se os prisioneiros eram despenhados dos altos, o deus a quem tais vítimas eram oferecidas não seria uma divindade dos montes? Quanto ao castigo dado aos parricidas, se não era praticado nem nos montes nem nos rios, não seria para não macular esses lugares ou para não ofender a benignidade de um deus dos montes que a ara de Minhotães (Barcelos) qualifica de "bom"?

Poderemos dizer que era mais cruento sacrificar inocentes prisioneiros de guerra do que parricidas. Não julguemos, porém, os homens do passado pelos nossos critérios éticos. Os prisioneiros de guerra poderiam ser homens bons, que não teriam transgredido nenhuma norma ética; os parricidas eram homens indignos. Assim, a um "bom" deus dos montes podiam sacrificar-se homens inocentes, mas não homens culpados de falta grave.

Também não deixa de ser curiosa a referência de Justino, Epítome, 44, 3 a um monte sagrado no território dos Callaeci que não se podia violar com instrumentos de ferro. Mas, neste caso, trata-se, aparentemente, de um monte concreto.

Crougiai, se acaso foi deus protector da etnia, poderia eventualmente ter função similar à do misterioso Quirinus romano (OLMSTED, 1994: 143; DUMÉZIL, 1958: 50-52 e 1996: 246-271).

Crougiai é enigmática divindade, não obstante parecer pacífica a relacionação do seu nome com IE *kreuk-, "colina, monte ou montão". Do que acabámos de dizer deduz-se, uma vez mais, que a análise linguística nem sempre é seguro ou suficiente caminho para definir as funções de uma divindade, mesmo que, na indagação das funções, devamos dar a maior importância às etimologias. Mas as dificuldades de, através das análises linguísticas, definirmos o perfil das divindades é ainda maior quando os linguistas entre eles divergem. É o caso de outra divindade nacional dos Callaeci, Cossue/Coso. 


\section{COSSUE/COSO}

Parecem opor-se à interpretação deste deus como divindade nacional dos Callaeci os dois testemunhos de Cosei Vacoaico e Cusei Paeteaico (ou Baetaico). O primeiro encontra-se numa ara que se guarda no Museu Regional de Viseu. Apesar de ser desconhecida a sua proveniência, não temos razões sérias para duvidar do seu achado na região, em qualquer lugar da bacia do rio Vouga, o Vacua de Estrabão, III, 3, 4, o Vagia de Plínio, IV, 35, 113, o Vaco de Ptolemeu, II, 5, 3. Quanto à ara de Cusei Paetaico, foi encontrada em Aguada de Cima (Águeda, Aveiro).

A área destas duas inscrições não faria parte do território dos Lusitanos tal como o definimos. Mas integraria a dos Calaicos? Se é aparente uma considerável diferença de cultura material do Bronze Final e da Idade do Ferro a ocidente e a oriente da serra da Estrela (exceptuados os objectos metálicos do Bronze Final, que manifestamente ultrapassam fronteiras étnicas), é mais incerta a proximidade da cultura material do Noroeste peninsular e da Beira Central (ainda que muitos autores sustentem a difusão da "cultura castreja" até ao rio Vouga). É possível que os Callaeci, descendo ao longo do litoral, tenham tomado o rio Vouga como via de penetração no interior.

Algumas inscrições a Cossue/Coso foram encontradas na região de El Bierzo (León). Se é certo que esta se integra no que foi, na época romana, conventus Asturum, não é menos verdade que tal área tem manifestas afinidades com a Galiza (MAÑANES, 1981; DOPICO CAÍNZOS, 1988: 20; ALARCÃO, 2003a: 19). É possível que o conventus Asturum tenha integrado, na sua parte ocidental, uma área que, em época proto-histórica, pertencia aos Callaeci e que, mesmo em época romana, tinha mais afinidades com o conventus Lucensis do que com os Ástures.

Relacionando o teónimo com uma raiz IE *kom-dhH-tu, que significaria "reunião, conjunção, encontro ou confluência", Blanca María Prósper (1997: 284; 2002: 239-241) fez desta divindade um deus das confluências fluviais. Carlos Búa (2003), porém, relacionou o nome com temas que, na sua forma verbal e nominal, respectivamente, significariam "co-habitar, conviver" e "habitações juntas". 
Não podemos, no campo estrito da linguística, pronunciar-nos sobre a maior ou menor justeza de cada uma destas propostas. Mas (insistimos mais uma vez) as análises linguísticas devem ser julgadas também por considerações extra-linguísticas. Ora que necessidade teriam os Calaicos de invocar outro deus dos rios se já o tinham em Reve? Poderiam, é certo, venerar génios locais de rios. Mas não é o caso de Cossue/Coso, que, pela sua larga difusão, não pode incluir-se na categoria dos genii.

Pelo contrário, a proposta de Carlos Búa, fazendo de Cossuel Coso um deus que reunia e protegeria uma comunidade (fossem os todos da família ou os habitantes todos de um povoado, ou ainda a população de vários castros), não se nos afigura um sem-sentido.

Os castros, de um modo geral, eram pequenos povoados que não excederiam escassas dezenas de famílias. As grandes citânias como Briteiros e Sanfins eram a excepção, não a regra. De qualquer forma, só se desenvolveram numa época tardia da Idade do Ferro.

As populações castrejas, assim dispersas por pequenos núcleos, teriam necessidade de se encontrar de quando em quando, eventualmente em terreno neutro, num momento que seria de festa, de troca económica, de acordos matrimoniais. À visão de uma sociedade castreja em que a guerra seria endémica, mesmo que reduzida ao roubo recíproco de gados, contrapomos nós um outro entendimento: o de uma sociedade que, como garantia da sua própria sobrevivência, valorizaria a solidariedade - ainda que esta pudesse existir só ao nível de pequenas regiões, as quais até poderiam ter corónimos próprios, como Madia (hoje, Maia), ou Anegia (onde se adoravam os Lares Anaeci) ou Burium (onde se veneravam os Lares Burici) (SILVA,1986: 277-278).

Um deus que se invocasse como garantia da boa convivência, da solidariedade, da fidelidade aos pactos, tem fácil explicação neste contexto. Seria Cossue/Coso?

Poderemos argumentar que essa função era a de Bandue/Bandi, cujo nome significaria "atar, manter unido, vincular". Mas, como atrás vimos, outra etimologia parece mais credível para Bandue/Bandi, fazendo dele um Júpiter indígena.

Se o deus Cossue/Coso protegia os povoados, seria ele a figura representada nas famosas estátuas de guerreiros galaicos que se erguiam 
nas muralhas dos castros, junto às entradas? Temos sustentado que as estátuas representavam príncipes (ALARCÃO, 2003b) e não nos desmentiremos enquanto não surgirem provas do contrário. A duvidosa leitura proposta por Carlos Alberto Ferreira de Almeida para supostas letras existentes na base de uma estátua de guerreiro de Monte Mozinho (ler-se-ia aí Deo Coso) não se confirma (CALO LOURIDO, 1994: 343 344). Mas não é inadmissível que o princeps tenha assumido, na fase final da "cultura castreja", uma função que, em época mais recuada, seria a do deus Cossue/Coso. Este poderia ter tido, entre os Callaeci, a função do Hermes arcaico grego, que Jean Pierre Vernant (1971: 127) sugestivamente descreve desta forma: "Em casa, o seu lugar é à porta, protegendo a entrada, repelindo os ladrões [...]; senta-se à entrada das cidades, nas fronteiras dos Estados, na cruz dos caminhos, ao longo dos caminhos, marcando a rota [...]. Em todos os lugares em que os homens, saindo de suas casas, se reúnem e contactam para discutir ou comerciar... aí está Hermes".

Os epítetos Esoaecus e Oenaecus, com que Cossue/Coso foi invocado, se acaso se relacionam com uma raiz IE *ei- , "ir, correr" ou *eis-/is-, "mover-se com rapidez", sugerem também uma identificação com um Hermes. Cossue/Coso seria uma divindade galaica homóloga do Quangeius lusitano?

A tentativa de equacionação de uma divindade indígena do Ocidente peninsular com divindades do panteão greco-latino, sendo útil, tem de ser prudente. O carácter multifário das divindades indígenas torna sempre ambígua a interpretatio. Disso dá testemunho eloquente o facto de a mesma divindade indígena ter sido, na Gália, identificada por uns (ou nalguns lugares) com Marte e por outros (ou noutros lugares) com Mercúrio.

Assumindo, para Cossue/Coso e Crougiai o "estatuto" de divindades nacionais dos Calaicos, podemos perguntar-nos qual seria a situação existencial deste povo e que deuses lhe seriam necessários. Os homens vivem num lugar e, ao mesmo tempo, vivem com outros homens. A situação existencial de viver com outros homens, num grupo (ou em grupos sucessivamente mais abrangentes: o da família restrita, o da linhagem, o do povoado, o da rede de vários povoados), não exigiria uma divindade que garantisse a coesão social? Seria Cossue/Coso? A situação existencial de viver no "espaço" da montanha, que não era um 
espaço cartesiano, mas um espaço vivido, que se explorava economicamente e diariamente se percorria apascentando os gados, não exigiria um deus mais relacionado com tal espaço? Seria Crougiai? As duas divindades devem ser pensadas em conjunto, para não multiplicarmos funções. Se a função mais credível para Cossue/Coso nos parece ser a de Hermes, teremos de voltar às várias hipóteses que atrás apresentámos para Crougiai e, excluindo agora a de uma equivalência com Mercúrio, optar pela de um deus que, senhor dos montes, se aproximaria de um Silvanus ou Marte agrário.

\section{Haveria divindades tutelares de populi?}

As etnias de Lusitani e Callaeci integrariam unidades étnicas menores, a que chamaremos populi. Não voltaremos aqui à hipotética identificação dos populi que integrariam os Lusitani, embora reconhecendo que a nossa proposta (ALARCÃO, 2001) exige confirmação e (ou) revisão. Quanto aos populi que compunham os Callaeci, o estudo de A. Tranoy (1981) permanece como a melhor análise sobre o assunto. O problema fundamental reside agora na localização e delimitação desses populi (ALARCÃO, 1998; RODRÍGUEZ COLMENERO,1997, II: 13-14).

Tal como noutras províncias do império romano, os populi foram convertidos em civitates - embora se não deva ter por certa (e talvez nem sequer como normal) a total coincidência das civitates com os populi pré-romanos. No nosso estudo sobre os Lusitani (ALARCÃO, 2001: 312-314) levantámos o problema de saber se os populi pré-romanos tinham, cada um deles, uma divindade própria. Não chegámos a nenhuma conclusão convincente.

A existência de uma ara a Igaedus junto da capela de Nossa Senhora do Almortão (Idanha-a-Nova), no território dos Igaeditani, e de um altar a Callaicia, no território dos supostos Callaeci sensu stricto, pode levar-nos a julgar que cada populus tinha, de facto, uma divindade própria, tutelar. Por outro lado, a dificuldade de identificarmos, para a maioria dos populi, estas supostas divindades tutelares leva-nos a considerar com sérias reservas a ideia. Igaedus e Callaicia não seriam divindades alegóricas, criadas já na época romana, a exemplo das "divindades" que personificavam as províncias? Dar-se-á o caso de terem 
sido, inicialmente, herói e heroína epónimos, de quem os populi, nos relatos míticos das suas origens, se considerariam descendentes?

Relativamente aos Callaeci, e para além de Callaicia, apenas o deus Carus, testemunhado por várias aras todas encontradas numa reduzida área do vale do rio Vez, se apresenta como candidato a divindade tutelar de populus (ALARCÃO, 2002: 345). Mas a hipótese de se tratar de uma divindade local, adorada em um qualquer monte, não deve ser posta de lado.

Se acaso os Zoelae, embora administrativamente integrados pelos Romanos no conventus Asturum, faziam parte da etnia dos Callaeci, poderíamos acrescentar Aernus à lista das possíveis divindades tutelares de populi (REDENTOR, 2002: 227-229).

Em conclusão: não rejeitando inteiramente a ideia de uma divindade tutelar de cada populus, eventualmente ligada a um mito de origem, manifestamos as nossas sérias dúvidas neste assunto, dada a incapacidade de identificarmos um número suficientemente significativo de divindades que poderiam ter tido esta natureza.

\section{GENII E SIMILARES}

Certas "divindades" atestadas por inscrições únicas, ou por várias epígrafes mas todas procedentes de um mesmo lugar, devem considerarse como genii loci, lares, junones ou nymphae, isto é, como divindades tópicas moradoras em concretos locais, fossem montes ou vales, fragas ou grutas, fontes ou rios, lagos ou pântanos, passagens a vau num rio, desfiladeiros, prados, campos de semeadura.

Alguns dos nomes, precedidos, nas aras, pelas palavras genio, lari ou laribus, junoni ou nymphae, não suscitam dúvidas. Genio Laquiniensi, Laribus Cerenaeci, Iunoni Linteaicai, Nymphae Lupianae, etc., são exemplos destas "divindades" menores e tópicas.

Casos como os de Abne, Luruni, Vestius Aloniecus e muitos outros, por não virem precedidos por aquelas palavras designativas de "divindades" menores e tópicas, podem suscitar dúvidas.

Abne, testemunhada por uma ara de Santo Tirso (Porto), seria a deusa do rio que por ali passava, o Ave. Na ara lê-se: $D$ (eae) D(ominae) $N($ ostrae) Abne, isto é, "À deusa e nossa senhora o rio"- porque abnis, nome comum de "rio", era do género feminino. Os adoradores do rio 
Ave terão posto uma ara ao rio (ou à senhora do rio) sem especificarem o nome próprio das águas porque, no contexto, era evidente a que rio se referiam. O caso não surpreende. Ainda hoje, a população de uma aldeia ou cidade diz "Vamos ao rio", sem mencionar o nome próprio do curso de água, porque é óbvio a que rio se referem as pessoas que dizem "Vamos ao rio".

Já no caso da ara, também única, a Dorius, a dedicatória terá expresso o nome próprio do rio.

O deus Luruni, atestado por várias aras, mas todas encontradas em Vendas de Cavernães (Viseu), seria "o senhor da rocha ou o senhor da gruta ou o senhor da pedra" (PRÓSPER, 2002: 186-187).

O "deus" Vestius Aloniecus, se seguirmos a interpretação de Blanca María Prósper (2002: 221-222), seria a "divindade" protectora do prado de Alona. Este nome seria o do próprio prado ou o da aldeia cujos habitantes explorariam o prado.

Os lares ou nymphae podiam ser singulares ou plurais. Estarão neste último caso: Ariounis Mincosegaeigis (Santomé de Nocelo, Porqueira, Orense) ou Suleis Nantugaicis (El Condado, Prebenda, Orense).

Não deve surpreender-nos esta adoração de divindades tópicas. Também os Romanos, como dissemos, chegavam a extremas particularizações, como atestam aras ao Genius Macellum de Braga ou ao Genius Baselecae de Aeminium (Coimbra), génio do mercado e génio da basílica.

Alguns casos podem ser motivo de controvérsia. Citaremos, como exemplos, Aetius, Laneana, Erbine.

Aetius surge atestado em duas aras, uma em Alcaria (Fundão, Castelo Branco), outra no Sabugal (OSÓRIO, 2002). Se o nome deriva de raiz indo-europeia que significaria "dar" (PRÓSPER, 2002: 283), poderíamos ter em Aetius um simples epíteto; ou temos genii homónimos em Alcaria e no Sabugal?

Laneana está atestada em Torreorgaz (Cáceres) e em Aldeia da Ponte (Sabugal, Guarda). Pode tratar-se de epíteto, baseado num nome de lugar que se repetiria. Se este topónimo era Lanea, haveria dois lugares com o mesmo nome, um na província de Cáceres e outro no Sabugal. As "ninfas" Laneanae dos dois lugares seriam divindades diferentes, mas homónimas. 
O caso de Erbine é mais complexo. Com o epíteto de Iaedi(tanae)/ Iaidi(tanae), que se refere aos Igaeditani, e com o de Cantibidone, foi adorada em Segura (Idanha-a-Nova, Castelo Branco). O epíteto Cantibidone pode referir-se a uma pedreira (PRÓSPER, 2002: 217-218) ou a uma região pedregosa ou vale fragoso. Mas, agora sem epíteto, Erbine foi também adorada em Castillejos (Salvatierra de Santiago) e em Ibahernando (Cáceres). Se Erbine era um genius loci da passagem do rio Erges em Segura, poderia ter sido venerada no local. Mas alguém que partisse de lugar vizinho e devesse passar por esse ponto que era morada de Erbine (eventualmente de trânsito difícil), poderia, antes de partir, consagrar-lhe uma ara. Ou consagrá-la no regresso.

Não pretendendo sustentar que a hipótese formulada constitui correcta interpretação para o caso de Erbine, queremos apenas, com este exemplo, dizer que não se nos afigura inverosímil que um genius loci tenha sido venerado a uma certa distância do local que era sua morada. Da mesma maneira, podemos imaginar que o genius loci de umas águas termais tenha sido venerado longe dessas termas por quem, curado ou beneficiado por elas, regressasse à terra onde vivia.

Munidi, que, salvo numa inscrição rupestre de Celorico da Beira (Guarda), possivelmente incompleta, surge com epítetos tópicos, Eberobrigae, Igaed(itanae) e Fidenearum, talvez se deva incluir na categoria dos génios. Se a raiz do nome é IE *men- ou * mon-, "cabeça, monte" (PRÓSPER, 2002: 189), poderia este génio (feminino) ser específico de pontos altos?

Consideramos inútil prosseguir com a argumentação de que muitos dos "teónimos" são nomes de simples genii loci. Esta interpretação é hoje pacífica. Seria conveniente publicar-se uma lista actualizada dos genii, mas não é este o lugar adequado par fazê-la.

\section{Conclusão}

Reduzidos a epítetos (de natureza locativa ou qualificativa) muitos dos nomes que, durante muito tempo, se tomaram como teónimos, e reduzidos também muitos dos "deuses" à condição ou natureza de simples genii locais, são afinal poucos os deuses de Lusitanos e Calaicos.

As propostas que apresentámos sobre as funções dos deuses devem considerar-se como sugestões para futura investigação, que linguistas, 
especialistas da história comparada das religiões indo-europeias e arqueólogos dedicados à história económica e social das sociedades da Idade do Ferro da Hispânia dita "céltica" devem conduzir em estreita colaboração.

\section{REFERÊNCIAS}

Alarcão, Jorge de (1988) - O domínio romano em Portugal. Lisboa

Alarcão, Jorge de (1990) - "Divindades da Beira: ensaio de geografia religiosa", in GAMITO, Teresa Júdice (coord.), Arqueologia Hoje. I. EtnoArqueologia. Faro: 146-169

AlARCÃo, JoRGE DE (1998) - “Ainda sobre a localização dos populi do conventus Bracaraugustanus", Anales de Arqueologia Cordobesa, 9: 51-57

Alarcão, Jorge de (2001) - "Novas perspectivas sobre os Lusitanos (e outros mundos)", Revista Portuguesa de Arqueologia, 4(2): 293-349

AlARCÃo, JoRGE DE (2002) - "Sobre alguns problemas de etnonímia e toponímia do Noroeste de Portugal", in BOULLÓN AGRELO, Ana Isabel (ed.), Novi te ex nomine. Estudos filolóxicos ofrecidos al Prof. Dr. Dieter Kremer. Corunha: 337-349

AlarCÃo, Jorge de (2003a) - “A organização social dos povos do Noroeste e Norte da Península Ibérica nas épocas pré-romana e romana". Conimbriga, 42: 5-115

Alarcão, Jorge de (2003b) - “As estátuas de guerreiros galaicos como representações de príncipes no contexto da organização políticoadministrativa do Noroeste pré-flaviano". Madrider Mitteilungen, 44: 116126

Albertos, Maria de Lurdes (1977) - "Perduraciones indígenas en la Galicia romana: los castros, las divinidades y las organizaciones gentilícias en la epigrafia", Actas del Coloquio Internacional sobre el bimilenário de Lugo. Lugo: $17-27$

Albertos, Maria de Lurdes (1987) - “A propósito de algunas divinidades lusitanas", Actas del IV Colóquio sobre lenguas y culturas paleohispánicas. Vitória: 469-474

Belayche, Nicole et alii (2005) - Nommer les dieux. Théonymes, épithètes, épiclèses dans l'Antiquité. Turnhout

Blanco Freijeiro, A. (1959) - "Pátera argêntea com representação de uma divindade lusitana". Revista de Guimarães, 69: 453-457

Blázquez, José María (1962) - Religiones Primitivas de Hispania. Roma

BlázQuez, José MARÍA(1975) - Diccionario de las religiones prerromanas de Hispania. Madrid 
Bonnaud, Christophe (2002 - "Les divinités indigènes de Vettonie sous le Haut-Empire romain: essai d'inventaire et interpretation". Conimbriga, 41: $63-103$

BRAÑAS ABAD, R. (2007) - "Entre mitos, ritos y santuários. Los dioses galaicolusitanos", in GONZÁLEZ GARCÍA, F. J. (coord.), Los pueblos de la Galicia céltica: $377-443$

Búa, Carlos (2003) - “Cosus. Un exemplo de epigrafia e relixión”. Boletin Auriense, 33: 147-184

Calo Lourido, Francisco (1994) - A plástica da cultura castrexa galegoportuguesa. Corunha

Curado, Fernando Patrício (2002) - “A ideologia tripartida dos Indoeuropeus e as religiões de tradição paleohispânica do Ocidente peninsular”, in RIBEIRO, J. Cardim (coord.), Religiões da Lusitânia. Loquuntur Saxa. Lisboa: 71-77

Dias, Lino TaVAres (1997) - Tongobriga. Lisboa

Dias, Maria Manuela Alves (2001) - Epigrafia latina do Museu Municipal Hipólito Cabaço (Alenquer). Lisboa

Dopico CAínzos, M Dolores (1988) - La Tabula Lougeiorum. Estudios sobre la implantación romana en Hispania. Vitoria-Gasteiz

Dumézil, Georges (1958) - L'idéologie tripartite des Indo-Européens. Bruxelas

Dumézil, Georges (1966) - La réligion romaine archaique. Paris

EDMONDSON, JoNATHAN (1992-1993) - "Creating a provincial landscape: Roman imperialism and rural change in Lusitania" in Studia Historica. História Antigua, 10-11: 13-30

EnCARnAÇão, José D’ (1975) - Divindades indígenas sob o domínio romano em Portugal. Lisboa

EnCARnaÇão, José D’ (1985) - “Ara votiva a Triborunis”. Ficheiro Epigráfico, $14, n^{\circ} 59$

Frisk, HJalmar (1960) - Grieschischte etymologisches Worterbuch, I. Heidelberg

Garcia, José Manuel (1991) - Religiões antigas de Portugal. Lisboa

García FernándeZ-Albalat, Blanca (1990) - Guerra y religión en la Gallaecia y la Lusitania antiguas. Corunha

Guerra, Amílcar (1998) - Nomes pré-romanos de povos e lugares do Ocidente peninsular. Lisboa (Tese de doutoramento, policopiada, apresentada à Faculdade de Letras de Lisboa)

Hoz, Xavier (1986) - "Manifestaciones religiosas en la Lusitania", in Primeras Jornadas sobre manifestaciones religiosas en la Lusitania. Cáceres: 32-49

Jufer, N. E Luginbuhl, T. (2001) - Répertoire des dieux gaulois: les noms des divinités celtiques connus par l'épigraphie, les textes antiques et la toponymie. Paris 
Le Roux, PAtrick (1994) - Cultes indigenes et réligion romaine en Hispanie sous l' Empire" in LE BOHEC, Yann (coord.), L'Afrique, la Gaule, la religion à l'époque romaine. Mélanges à la mémoire de Marcel Le Glay. Bruxelas: 560-567

Le Roux, P. e Tranoy, A. (1974) - “Contribution à l'étude des régions rurales du N.O. hispanique au Haut-Empire: deux inscriptions de Penafiel”. Actas do III Congresso Nacional de Arqueologia (Porto 1973). Porto: 249-258

Mañanes, Tomás (1981) - El Bierzo prerromano y romano. León

MUÑOZ, ViRgINIA (2005) - "La interpretatio romana del dios prerromano Bandue". Veleia, 22: 145-152

Olivares Pedreño, Juan Carlos (2001-2002) - "Teónimos y fronteras étnicas: los Lusitani". Lucentum, 19-20: 245-256

Olivares Pedreño, Juan Carlos (2002) - Los dioses de la Hispania céltica. Madrid

Olmsted, Garrett S. (1994) - The gods of the Celts and the Indo-Europeans. Budapeste

Osório, Marcos (2002) - “Ara votiva encontrada no Sabugal”. Ficheiro Epigráfico, 69, no 309

Pedrero, Rosa (1999) - “Aproximación linguística al teónimo lusitano-gallego Bandue/Bandi" in VILLAR, F. e BELTRÁN, F. (coords.), Pueblos, lenguas y escrituras en la Hispania prerromana (Actas del VII Colóquio sobre Lenguas y Culturas paleohispánicas). Salamanca: 535-543

Pedrero, Rosa (2000) - "Sobre la etimologia de los teónimos: el caso del dios galaico-lusitano Bandi/Bandue”. In Miscelánea léxica in memoria de Conchita Serrano. Madrid: 417-426

Prósper, Blanca María (1997a) - “Tongoe Nabiaigoi: la lengua lusitana en la inscripción bracarense del Ídolo de la Fuente". Veleia, 14: 163-176

Prósper, Blanca María (1997b) - "La divinidad paleohispana Cossue/Coso y el dios itálico Consus". Aiôn .Annali del Istituto Universitario Orientali di Napoli, Dipartimento di Studi del Mondo Clasico e del Mediterraneo Antico. Sezione Linguistica, 19: 267-302

Prósper, Blanca María (2002) - Lenguas y religiones prerromanas del Occidente de la Península Ibérica. Salamanca

Redentor, ARMANDo (2002) - Epigrafia romana da região de Bragança. Lisboa

Redentor, Armando; Osório, Marcos; Carvalho, Pedro C. (2006) - "Inscrição rupestre da Lage do Adufe: um novo testemunho do culto à deusa Nabia". Eburobriga, 4: 51-59

R.L., L.S.= Religiões da Lusitânia. Loquuntur Saxa. Coord. J. Cardim Ribeiro. Lisboa, Museu Nacional de Arqueologia, 2002 
Richert, Elizabeth A. (2005) - Native religion under Roman domination. Deities, springs and mountains in the north-west of the Iberian Peninsula. Oxford (=BAR International Series 1382)

Rodríguez, Pilar (1996) - Gens. Una forma de agrupación antigua mal conocida.Vitória-Gasteiz

Rodríguez Colmenero, António (1987) - Aquae Flaviae. I. Fontes Epigráficas. Chaves

Rodríguez Colmenero, António (1997) - Aquae Flaviae. II. O tecido urbanístico da cidade romana. Chaves

Rodríguez Colmenero, ANTÓNIO (1999) - O santuário rupestre galaico-romano de Panóias (Vila Real, Portugal). Novas achegas para a sua interpretação global. Vila Real

Rodríguez Colmenero, Antónioo (2000) - “Deorum temene. Espacio sagrado y santuários rupestres en la Gallaecia romana. Un intento de clasificación", in Actas do $3^{\circ}$ Congresso de Arqueologia Peninsular, vol. VI, Arqueologia da Antiguidade na Península Ibérica. Porto: 153-195

Salvado, Pedro; Rosa, Joẽo Mendes; Guerra, Amílcar (2004) - "Um monumento votivo a Arância e Arâncio, proveniente de Castelejo (concelho do Fundão). Revista Portuguesa de Arqueologia, 7 (2): 237-242

Schattner, Thomas; Suárez Otero, José; Koch, Michael (2004) - "Monte do Facho, Donón (O Hío/Prov. Pontevedra) 2003. Informe sobre las excavaciones en el santuário de Berobreo". Archivo Español de Arqueologia, 77: 23-71

Silva, Armando Coelho Ferreira da (1986) - A cultura castreja no Noroeste de Portugal. Paços de Ferreira

Tranoy, Alain (1981) - La Galice romaine. Recherches sur le nord-ouest de la péninsule ibérique dans l' Antiquité. Paris

UNTERMANN, JURGEN (1985) - “Los teónimos de la región lusitano-gallega como fuente de las lenguas indígenas", in HOZ, Javier de (ed.), Actas del III Colóquio sobre lenguas y culturas paleohispánicas. Salamanca: 343-363

Vasconcelos, J. Leite de (1905 e 1913) - Religiões da Lusitânia. Lisboa, vols. II e III

VAz, JoÃo L. Inês (1997) - A civitas de Viseu. Espaço e Sociedade. Coimbra Vernant, Jean Pierre (1971) - Mythe et pensée chez les Grecs. I. Paris

VILlar, Francisco (1996) - "El teónimo lusitano Reve y sus epítetos", in MEID,

Wolfgang e ANREITER,Peter (coord.), Das grosseren altkeltischen Sprachdenkmaler. Akten des Kolloqiums Innsbruck. Innsbruck: 160-211. 